\title{
Entre a igreja e o mundo: Identidades em construção na era do Concilio Vaticano II
}

\author{
Between the church and the world: Identities under
}

construction in the era of Vatican Council II

JoÃo DÉCIO PASSOS (iDa

\section{Resumo}

Os perfis dos padres investigados expressam as duas tendências eclesiais: institucional/carismática e evangelização/libertação. A reflexão examina tanto as tendências quanto os resultados expressos pelos dados levantados. Assume o processo de aggiornamento inaugurado pelo Vaticano II como epicentro das tendências, sendo a fonte de onde brotam a postura renovadora e a postura institucionalizada e individualizada dos dois perfis. A recepção e interpretação do evento conciliar desencadeou um processo histórico-eclesial que se torna cada vez mais ambíguo, na medida em que o carisma conciliar rotiniza-se e uma política eclesial restauradora vai afirmando modelos tradicionais de ministério presbiteral. Os dois perfis de padres analisados são as expressões dessa ambiguidade de fundo e da atual fase de recepção do Vaticano II na Igreja do Brasil.

Palavras-chave: Aggiornamento. Igreja. Institucionalização. Ministérios. Recepção.

\section{Abstract}

The profiles of the priests investigated express the two ecclesial trends: institutional/charismatic and evangelization/liberation. The reflection examines both the trends and the results expressed by the numbers. It assumes the process of

\footnotetext{
a Pontifícia Universidade Católica de São Paulo (PUC-SP), São Paulo, SP, Brasil. Doutor em Teologia, e-mail: jdpassos@pucsp.br
} 
aggiornamento inaugurated by Vatican II as the epicenter of the tendencies, being the source from which the renewing stance and the institutionalized and individualized stance of the two profiles spring. The reception and interpretation of the conciliar event has triggered a historical-ecclesial process which becomes more and more ambiguous, as the conciliar charism becomes routine and a restorative ecclesial policy affirms traditional models of priestly ministries. The two profiles of priests analyzed are the expressions of this basic ambiguity and of the current phase of reception of Vatican II in the Brazilian church.

Keywords: Aggiornamento. Church. Institutionalization. Ministries. Reception.

\section{Introdução}

As questões analisadas nesse artigo dizem respeito às relações entre a Igreja e o mundo e vice-versa. Os agentes eclesiais manifestam suas percepções em relação à missão da Igreja no mundo e à visão da sociedade atual sobre a Igreja. Trata-se, de fato, da questão central que provocou e direcionou o próprio Concilio Vaticano II e, por conseguinte, todo o processo de recepção de suas orientações desde 1965. Os dois grupos de padres pesquisados indicam, por si mesmos, um aspecto significativo dessa recepção que, longe de constituir uma unanimidade eclesial e de construir configurações estáveis, conheceu dissensos e conflitos, o que hoje se desenha com relativa nitidez. A imagem de uma Igreja toda renovada foi aos poucos mostrando sua projetividade, vulnerabilidade e pluralidade interna, na medida em que o tempo passava e o projeto do Vaticano II se posicionava em um marco mais distante. Essa realidade se mostra hoje nua e crua em posicionamentos de agentes e grupos eclesiais tradicionalistas no seio da Igreja, o que nos faz preguntar: onde estivemos e para onde vamos? Os resultados hora analisados fornecem elementos que confirmam essa ambivalência e essa ambuiguidade eclesial de fundo e indicam as diferentes posições dos ministros ordenados em distintos contextos históricos.

Vale recordar que a reflexão sobre os dados pesquisados é um exercício hermenêutico que articula elementos empíricos induzidos da realidade em um determinado tempo e espaço com pressupostos teóricos; trata-se de uma construção circular que conta com dois limites inevitáveis: aqueles inerentes a toda indução (sempre situada, delimitada e fragmentada) 
e aqueles próprios de todo pressuposto (pré-noções que condicionam e até mesmo formatam as interpretações). É da natureza de toda interpretação o esforço de promover uma circularidade honesta e técnica que seja capaz de fazer a "fusão de universos", como explica Gadamer (2002, p. 400-425). Em outros termos, que seja capaz de construir um quadro compreensivo sobre aquilo que os dados apresentam de forma indicativa e fragmentária. Vale lembrar que, em toda pesquisa empírica, os dados não falam por si mesmos, mas, antes, são provocados a falar a partir de pressupostos que demarcam o foco a ser investigado (teorias, tipologias e categorias) e, a partir desses, os dados são capturados e revelam tendências, posturas e valores dos campos investigados. No caso aqui analisado, as duas perspectivas institucional/carismática e evangelização/libertação - emolduram o objeto de investigação e brotam obviamente de percepções teóricas (históricas, sociais e eclesiais) sobre a realidade eclesial. Elas expressam aquilo que já se sabe previamente sobre o objeto. Os dados empíricos verificam os traços concretos desse a priori teórico no momento histórico em que foi aplicada.

As reflexões a seguir serão estruturadas a partir dessa constatação de ordem metodológica: exposição dos pressupostos da pesquisa, olhar sobre os dados e interrogação sobre os significados dos dados. Toda interpretação simplifica o complexo, enquadra o plural em determinada moldura e expõe o que está por baixo, as causas ou os mecanismos tendenciais. As atitudes de fidelidade aos fatos (mesmo que apenas indicativos) e ao quadro analítico constituem o primeiro ato da interpretação. O segundo ocorre na postura da coerência da articulação que se busca entre os dois polos. Sabendo desses limites e dessas possibilidades passamos aos três momentos da reflexão.

\section{Os pressupostos da pesquisa: as duas perspectivas eclesiais}

As duas perspectivas teológico-pastorais ou eclesiais estruturantes da pesquisa não nascem do nada e nem são classificações arbitrárias da realidade histórico-eclesial. Tomar consciência do significado dessas é o passo prévio para a compreensão dos dados que emergem, no segundo momento, como expressão dos agentes eclesiais que se encontram nelas inseridos e nesse lugar hermenêutico se esforça por interpretar a Igreja e o mundo. Elas 
são tipificações de processos históricos que marcaram e definiram os rumos da Igreja após as renovações trazidas pelo Concilio Vaticano II (a assimilação institucional do clero progressista, de outro, dilui sempre mais o que fora bem distinto). Os padres novos e os da década de setenta são sujeitos emblemáticos desse processo e, em suas realidades concretas atuais, indicam as diferentes percepções de realidade e de Igreja.

As interrogações focadas nos dois grupos estão inseridas no centro da eclesiologia - da visão e da práxis eclesial - demarcada pelo Vaticano II e, por conseguinte, no interior de todo o processo de recepção do mesmo em nosso contexto latino-americano e brasileiro. As duas questões trazem à tona as contradições desse processo histórico-eclesial, quando a unanimidade eclesial que brotou do Concílio foi conhecendo divergências e agregando tendências cada vez mais nítidas dentro da Igreja, até configurar posições distintas e divergentes. A luta pelo verdadeiro sentido do Vaticano II (FAGGIOLI, 2013) fez parte do processo conciliar, embora na fase inicial o projeto de aggiornamento (cf. ALMEIDA, 2015, p. 8-9) tenha mostrado seu vigor criativo nas Igrejas da América Latina, onde foi traduzido em experiências eclesiais concretas e em métodos teológicos bem estruturados e originais. A distância histórica do evento conciliar ocasionou a inevitável "rotinização do carisma" (WEBER, 1997, p. 197-201), ao mesmo tempo em que, do ponto de vista oficial, avançavam as estratégias de retomada de uma práxis eclesial centralizadora, desde o epicentro da Cúria romana. As perspectivas ou tendências eclesiais/eclesiológicas compuseram conjunturas tensas entre o centro e as periferias, entre tradição e renovação, entre magistérios locais e magistério papal e entre modelos de Igreja autocentrados e abertos ao diálogo. As tendências detectadas e ora examinadas se inserem nesse processo de construção social (eclesial); constituem frentes que se sustentam em modelos eclesiais distintos. As duas denominações indicam de modo tipológico as posições centradas nas perspectivas evangelização/libertação e institucional/carismática, representando cada qual as forças de renovação e preservação que se expandiram desde o epicentro conciliar (PASSOS, 2015).

Nas décadas seguintes ao Concílio, a luta pelo verdadeiro sentido do Vaticano II ocorria nas dimensões teórica e prática, ou seja, nos âmbitos do 
debate teológico e dos projetos concretos de aggiornamento que tomavam forma em nosso contexto. Se na década de setenta, no clima e no contexto do pontificado de Paulo VI, a perspectiva renovadora tomava forma nas Igrejas da América Latina e, no caso do Brasil, construía uma unanimidade cada vez mais visível, nas décadas seguintes vai sendo confrontada, esvaziada e, pouco a pouco, suplantada pela perspectiva conservadora que se se configura nos quadros oficiais da Igreja. A retomada da identidade católica constatada por Libânio no início da década de oitenta (1984) se deu por meio de políticas eclesiásticas adotadas pela Cúria romana e, evidentemente, por seus representantes legitimamente posicionados no corpo eclesial. As investidas romanas sobre as Igrejas Locais produziram efeitos gradativos que reconfiguraram a fisionomia da Igreja no continente, com a clara vantagem de se tratar de uma política oficial que se impunha pela força do ethos católico (centrado na comunhão e na fidelidade ao Papa), bem como amparada pela estrutura institucional que, na verdade, saíra intacta das renovações conciliares. A luta que se estabeleceu no interior da Igreja era evidentemente de ordem cultural (distintas representações sobe a natureza e a missão da Igreja), política (sujeitos concretos em confronto com seus distintos projetos) e institucional (normas oficiais que traduziam o projeto conservador).

Do ponto de vista sociológico, pode-se falar de modo tipológico em uma luta entre carismáticos (portadores de ideias renovadores) e institucionais (agentes oficiais munidos de normas preservadoras da tradição e da instituição) no campo religioso latino-americano. Os tipos puros profeta e sacerdote utilizados por Pierre Bourdieu (2003) para analisar as tensões no interior do campo religioso expressam analiticamente aquilo que as Igrejas da América Latina vivenciaram com seus projetos de renovação. O sacerdote tipifica os personagens que exercem a função de profissionais da ordem e da preservação, enquanto o profeta encarna a renovação dentro da instituição. São posições (e figuras) políticas antagônicas que buscam hegemonia dentro de um determinado sistema. O primeiro conta com a segurança da posição legítima e instituída que ocupa. O segundo conta com a força do seu discurso, do carisma que retoma como fonte renovadora que vem das origens. Por essa razão, o reformador é um construtor contínuo de legitimidade por meio 
de seus discursos e práticas que oferecem o dom da mudança, da revolução, da salvação etc. Ele possui a dupla tarefa de destruir o edificado e de edificar o novo. Nesse caso, o jogo de forças é sempre desigual e o sacerdote possui as ferramentas legais e eficazes para enfrentar o profeta reformador: eliminando-o como corpo estranho do corpo institucional - eliminação ideológica, simbólica, legal e, até mesmo, física - como herege, ou assimilando-o em seu mundo ordenado como renovador controlado. 0 reformador está investido da missão de convencer a todos, mesmo quando possui poucos adeptos. A tarefa de angariar discípulos ao seu projeto é necessária e sua força discursiva se reforça definitivamente à medida que consegue consensos mais amplos que lhe garantem apoio, expansão e realização. Os reformadores precisam, portanto, de armas discursivas e de estratégias políticas para que seus projetos possam concretizar-se.

Os pontificados de João Paulo II e Bento XVI adotaram uma política curial que levou adiante um projeto eclesial que foi definindo sempre mais as duas referidas frentes. A perspectiva institucional/carismática foi sendo construída e adquiriu maior força e visibilidade no corpo eclesial, o que nas décadas da renovação seria impensável. A frente renovadora representa, de fato, uma geração convicta da causa conciliar, porém institucionalmente assimilada e com protagonismo diminuído no seio da Igreja. A pesquisa investiga - ou confere de modo empírico - as posturas conhecidas das duas frentes.

\section{Os dados: sinais característicos das tendências}

As duas perguntas aqui em análise estão direcionadas para 0 aferimento de duas perspectivas precisamente inversa: da Igreja para o mundo (qual deve ser a postura da Igreja frente ao mundo de hoje?) e do mundo para a Igreja (como a sociedade em geral vê a Igreja, hoje?). A primeira aciona mais diretamente o imaginário eclesial/eclesiológico por trazer a luz uma determinada concepção da natureza e da missão da Igreja; a segunda, embora exija repostas pautadas mais na imaginação do que numa percepção logica ou empírica (exige imaginar o que os outros pensam de nós) toca nas relações do mundo com a Igreja, sociologicamente na função 
social da Igreja. Enquanto a primeira interrogação (respostas) conta com um capital teológico mais ou menos conhecido, a depender de cada sujeito eclesial, a segunda depara-se com um sujeito provavelmente desprovido de pressupostos sociológicos, restando, ao que parece, responder a partir do que imaginam que o mundo pense da igreja. Enquanto a primeira pode reproduzir um repertório eclesiológico mais ou menos consensual (conhecido na teoria e na prática), a segunda reproduz mais os imaginários individualizados. A armadilha cognitiva se mostra, por certo, inevitável: o que os outros pensam da Igreja acaba sendo, na verdade, o que cada sujeito "pensa que a sociedade pensa". O quadro geral revela esse isolamento individual e o recurso à imaginação. Por essa razão, as repostas se atrapalham quando confrontadas no conjunto e cada sujeito "se vira" como pode com suas percepções. A ausência de unanimidade entre os sujeitos pode revelar, de fato, essa posição conceitualmente vulnerável do entrevistado. Da mesma forma que o consenso curioso entre os jovens da perspectiva institucional/carismática e os seminaristas da perspectiva evangelização/libertação sobre a "instituição atrasada" indicam o condicionante etário da resposta: os jovens têm uma percepção comum dos atrasos da Igreja e operam com essa percepção.

\section{Os perfis eclesiais indicados pelos dados}

Com relação à pergunta 9 - qual deve ser a posição da Igreja frente ao mundo de hoje - é quase unanimidade a indicação em primeiro lugar de que a Igreja deve inserir-se, em postura de diálogo e serviço - padres (47,8\%), leigos/as $(25,9 \%)$ e seminaristas (24,1\%) da perspectiva “institucional/carismática"; e padres (53,1\%), leigos/as (21,5\%), jovens $(41,4 \%)$, seminaristas $(51,1 \%)$ e religiosas $(41,7 \%)$ da perspectiva “evangelização/libertação”. Exceção são os jovens (24,9\%) da perspectiva “institucional/carismática” que indicam que a missão da lgreja é espiritual, não importa o que o mundo pensa da Igreja (24,9\%) e as religiosas, da mesma perspectiva, que indicam sem confrontações, exercendo o profetismo anunciando e denunciando (25,0\%). 
Em segundo lugar, a incidência se dá em suas alternativas: dar seu exemplo, sendo mais missionário e presente no mundo, indicado por padres $(15,9 \%)$ e religiosas $(21,9 \%)$ da perspectiva "institucional/carismática" e por padres (22,9\%), leigos/as (14,6\%) e jovens (14,8\%) da perspectiva “evangelização/libertação"; e a Igreja inserir-se, em postura de diálogo e serviço, indicado leigos (20,3\%) e religiosas (21,9\%) da perspectiva “institucional/carismática" e por religiosas (18,1\%) da perspectiva “evangelização/libertação”. Também aparece em segundo lugar fortalecer a pastoral social e preparar os leigos para sua missão no mundo, mas somente para os seminaristas (14,9\%) e os leigos/as 11,3\%) da perspectiva “evangelização/libertação”. O que a aparece em primeiro lugar para as religiosas da perspectiva "institucional/carismática” — sem confrontações, exercer o profetismo, anunciando e denunciando, aparece em segundo lugar para os leigos/as $(20,3 \%)$ da mesma perspectiva e para as religiosas $(18,1 \%)$ da perspectiva "evangelização/libertação". Chama a atenção que os seminaristas da perspectiva "institucional/carismática" sejam os únicos a nomear evangelizar utilizando sobretudo os meios de comunicação social $(17,7 \%)$, seguidos pelos padres da mesma perspectiva, mas em quarto lugar. Também que fortalecer a pastoral social e preparar os leigos para sua missão no mundo seja nomeado somente os seminaristas e os leigos/as da perspectiva “evangelização/libertação". Em último lugar aparece o consenso referente às outras igrejas. Ambas as tendências não entendem por unanimidade ser missão da Igreja atrair católicos que migram para as igrejas pentecostais.

Com relação à pergunta 10 - como a sociedade em geral vê a lgreja, hoje - a resposta sobre como a sociedade em geral vê a Igreja hoje, entre as categorias de agentes eclesiais da perspectiva "institucional/carismática" os índices não demonstram convergência: os "padres novos" indicam uma instância ética, defensora da vida e dos direitos humanos (25,4\%); os leigos/as, uma prestadora de serviços religiosos, como outras religiões (34,5\%); os jovens, uma instituição atrasada, defendendo coisas ultrapassadas (36,8\%); os seminaristas entre religião e lgrejas, a que tem maior credibilidade (19,0\%); e as religiosas uma instituição com credibilidade e influência na sociedade (29,4\%). Já entre as categorias de agentes eclesiais da perspectiva “evangelização/libertação”, há maior consenso: indicam uma instituição com 
credibilidade e influência na sociedade os padres (32,3\%), leigos/as (22,4\%), jovens $(16,1 \%)$ e religiosas $(25,7 \%)$, enquanto que o os jovens nomeiam uma instituição rica defendendo seus próprios interesses (32,2\%) e os seminaristas uma instituição atrasada, defendendo coisas ultrapassadas (22,9\%). Como se pode contatar, há consenso dos seminaristas da perspectiva “evangelização/libertação” com os jovens da perspectiva “institucional/carismática”.

A indicação em segundo lugar tem maior consenso entre as categorias de agentes eclesiais da perspectiva "institucional/carismática” o que já haviam indicado as religiosas em primeiro lugar - uma instituição com credibilidade e influência na sociedade: padres (22,4\%), leigos/as (19,0\%), jovens $(16,1 \%)$ e seminaristas $(17,7 \%)$. Nesta perspectiva, as religiosas nomeiam uma instituição rica defendendo seus próprios interesses (20,6\%). Na perspectiva “evangelização/libertação”, nomeiam uma prestadora de serviços religiosos, como outras religiões: padres (16,7\%), leigos/as (21,4\%) e religiosas $(21,6 \%)$. Os jovens desta perspectiva, indo de encontro com os jovens e seminaristas da perspectiva “institucional/carismática”, que indicam em primeira opção uma instituição atrasada, defendendo coisas ultrapassadas (22,7\%). Os seminaristas nomeiam com o mesmo índice uma instituição com credibilidade e influência na sociedade e uma instância ética, defensora da vida e direitos humanos $(18,8 \%)$.

Chama a atenção que os "padres jovens" mencionem a visão de uma Igreja que está se metendo em questões que não lhe compete - indígenas, questões ecológicas e políticas (8,3\%), bem como defendendo o celibato obrigatório para os padres, quando deveria ser opcional (7,5\%). Os "padres das décadas de 1970/80" não se referem a estas alternativas. É de se pensar, de fato, que as duas tendências imaginem o pensamento dos outros em relação à Igreja a partir de suas convicções. Como também chama a atenção que a imagem de uma Igreja manchada pelo escândalo da pedofilia tenha índice tão baixo, ainda que os "padres das décadas de 1970/80" deem uma ênfase maior. 


\section{Alguns traços fisionômicos das tendências eclesiais}

O que os números revelam sobre as duas tendências teológicopastorais ou eclesiais? São duas gerações de padres que, de seus distintos contextos, mostram suas percepções sobre a Igreja e, de alguma forma, sobre a relação da mesma com o mundo. Os números trazem à luz traços de identidades eclesiais/clericais concretas, porém com fronteiras borradas, 0 que indica, de fato, não somente uma identidade fundamental católica onde as coisas se encontram e se misturam, como também o esforço de demonstrar o papel eclesialmente correto e os próprios limites de percepção dos entrevistados. Contudo, os números indicam o que a pesquisa supôs em suas categorizações: a emergência de uma figura nova de padre distinta daquela que marcou a Igreja no processo de recepção ativa do Vaticano II no contexto brasileiro.

\section{$1^{\circ}$ Tipologias/tendências borradas}

Os dados aferidos das perspectivas ou tendências não oferecem um quadro eclesial nítido; ao contrário, mostra uma espécie de foto difusa que, muitas vezes, mais "confunde" do que revela aquilo que já está estruturado como expectativa na classificação prévia das duas perspectivas: como dois grupos/perspectivas marcadamente distintos. A segunda interrogação como a sociedade atual vê a Igreja hoje revelou a quase ausência de consenso por parte dos agentes interrogados. Ainda que se possa pensar em dificuldades de responder sobre "o que os outros pensam", tratar-se-ia de uma dificuldade reveladora de um imaginário eclesial confuso que revela mais opiniões isoladas do que consensos mínimos além do que se pode pensar em uma distância (oposição ou indiferença) em relação à sociedade. Cada segmento pensa a sociedade a sua imagem e semelhança ou reproduz a visão a partir de seus lugares sociais. Os diretamente inseridos no corpo e eclesial (padres, religiosos e seminaristas) tendem a sugerir uma imagem mais teológica de Igreja (defensora da vida, credibilidade social e servidora), enquanto os leigos e jovens uma imagem mais negativa (prestadora de 
serviços religiosos, como outras religiões e instituição atrasada, defendendo coisas ultrapassadas).

Os dados convidam a um diálogo, na medida em indicam posições e interpretações dos agentes eclesiais. Pode-se dizer que as tipologias se mostram pouco nítidas não somente por razões metodológicas, mas por expressarem uma realidade empírica (os agentes eclesiais em seus lugares distintos dentro da mesma comunidade) composta de diversidades em termos práticos e teóricos. É igualmente verdadeiro que a fase de nitidez eclesial decorrente do projeto de renovação conciliar tem mostrado seus desgastes e cedido espaço para diversidades de projetos no seio da mesma comunidade eclesial. A emergência dos movimentos de linhagens individualizadas e espiritualizadas e a assimilação institucional do clero progressista dilui sempre mais o que fora bem distinto como projetos eclesiais. Nesse sentido é que se pode explicar que agentes (jovens e seminaristas) das duas tendências venham convergir sobre as posições atrasadas da Igreja, que as religiosas das duas tendências concordem sobre a missão da Igreja que deve sem confrontações, exercer o profetismo, anunciando e denunciando, que não haja consenso entre os agentes da perspectiva "institucional/carismática" sobre o uso dos meios de comunicação social, que não seja também consensual na perspectiva “evangelização/libertação" a importância da pastoral social e da preparação dos leigos para sua missão no mundo. As imagens contrastes dissolvem ainda suas fisionomias e se confundem em outros consensos: a respeito do não proselitismo da Igreja em relação às outras Igrejas e o baixo destaque sobre a problemática da pedofilia. Perante essas questões se esvaem os supostos eclesiocentrismo e moralismo da perspectiva institucional/carismática em contraste com a perspectiva evangelização/libertação. Ambas parecem retrair-se para dentro da zona segura do corpo eclesial e evitarem a autocrítica, bem como estratégias pastorais mais agressivas. O novo pode ser evitado, tendo em vista a exigência de formulações mais elaboradas? Nas duas posturas a rotina eclesial e a sobrevivência institucional prevalecem sobre o enfrentamento crítico. O que até algum tempo se definia pela imagem do contraste e da oposição, agora pode ser visualizado em paralelismos que não se tocam e, até mesmo, em posturas comuns. 
Não seria inútil para a reflexão interrogar sobre o que se configurava na Igreja renovadora das décadas anteriores à emergência explícita do clero de perfil institucional/carismático. Não há dúvidas de que o clero reprodutor da instituição sempre esteve presente ativo no seio da Igreja, porém sem protagonismo pastoral, atuando em posições burocráticas e na manutenção das ofertas sacramentais. A distinção entre os sacramentalistas e os pastorais demarcou as tendências do clero em décadas anteriores. Ademais, as diretrizes pastorais da Igreja latino-americana pautadas em critérios renovadores da Igreja e da sociedade instaurou uma cultura geral que abrigou a todos em modelos comuns.

\section{$2^{\circ}$ Resíduos eclesiológicos}

As mudanças históricas possuem uma dimensão cultural, explica Castells. São aquelas que se dão no âmbito das ideias e dos valores (2015, p. 353). Essas mudanças antecipam as mudanças políticas e institucionais e podem sobreviver para além das conjunturas concretas como imaginário consolidado ou como uma teoria consensual, semelhante ao que os epistemólogos denominam "ciência normal” (FOUREZ, 1995, p. 103-144). No caso em análise, como uma eclesiologia consensual ou como "eclesiologia normal" que se consolidou a partir do Vaticano II, embora em termos práticos tenha perdido gradativamente o vigor atrativo e a unanimidade política. Trata-se, no caso, de imagens, ideias e valores que sobrevivem como resíduos culturais, como “visão legítima” que ocupa um lugar relativamente estável no imaginário eclesial. A afirmação de que a lgreja deve inserir-se, em postura de diálogo e serviço expressa essa eclesiologia legítima e correta consolidada nos discursos oficiais. Do mesmo modo, a afirmação unânime, de que a Igreja não deve fazer proselitismo junto aos convertidos a outras igrejas revela uma atitude politicamente correta, antes de um suposto conformismo com o evidente trânsito religioso de católicos para o mundo pentecostal. Enquanto a primeira resposta revela um consenso teórico, a segunda aponta para um consenso prático em relação ao pluralismo religioso. 
As respostas indicam um senso comum eclesiológico do qual participam de modo mais explícito os sujeitos eclesiais diretamente inseridos no corpo eclesial, padres de ambas as perspectivas, assim como as religiosas e seminaristas. Inserir-se na sociedade em atitude de diálogo e serviço é uma verdade eclesial que, não obstante a extensão conceitual, não poderia não ser consensual. Na mesma direção insere-se o segundo lugar com a afirmação de que a Igreja deve dar seu exemplo, sendo mais missionário e presente no mundo. No caso, as diferentes compreensões que possa haver entre as tendências a respeito dos significados de "diálogo" e de "serviço" do "exemplo" e da "missionaridade" não implicariam em posturas diferenciadas. O acordo a respeito do enunciado eclesiológico dispensa no momento da resposta uma explicitação que indique "que tipo de serviço e a quem servir", assim como "como praticar o diálogo" e "como ser missionário". Quanto maior a extensão menor a compreensão, rezava a regra lógica clássica. E a maior extensão agrega diferentes compressões. Abaixo da generalidade, na medida em que as questões se delimitam, as posições manifestam os ângulos mais precisos: na perspectiva “institucional/carismática” os jovens revelam a visão espiritualizada de Igreja e, as religiosas, a visão harmônica. A dicotomia entre a teoria (eclesiológica) e a prática subjazem nas respostas que são consensuais nas questões gerais (nos princípios), mas se mostram distintas nas questões mais delimitadas e práticas. Nesse sentido, parece ser necessário observar o que não é unânime e até mesmo as pequenas dissonâncias para que se possa captar o real imaginário eclesial, como o uso dos meios de comunicação social na evangelização e acento na dimensão espiritual, mais espiritualidade e oração, destacado na perspectiva institucional/carismática.

Os agentes eclesiais supostamente mais instruídos teologicamente demonstram maior unanimidade eclesiológica, independente da perspectiva, enquanto os sujeitos menos instruídos, no caso os jovens, tendem a destoar dos demais com suas respostas díspares. É o mundo das ideias eclesiológicas em contraste com o mundo das práticas eclesiais, sendo as contradições entre os dois mundos reveladoras da Igreja mais real na qual uma nova identidade ministerial se apresenta cada vez mais legitima na cena eclesial nacional. Essa confluência eclesiológica que abriga divergências eclesiais, 
podem indicar, também, a ausência de uma elaboração eclesiológica da parte da tendência institucional/carismática, embora exista como pressuposto subjacente às práticas. Em todo caso, a eclesiologia conciliar ainda sobrevive como a referência teórica comum das distintas identidades clericais, ainda que como um resíduo cultural sem grande força política.

\section{$3^{\circ}$ Crise da consciência social}

Essa crise pode ser vista nos aspectos internos e externos da vida da Igreja. Do ponto de vista interno diz respeito a uma crescente individualização das práticas e das percepções. A eclesiologia adotada pelo Vaticano II rompe em sua percepção de fundo com a eclesiologia centrada na hierarquia até então definidora da Igreja. A sociedade estruturada na distinção foi substituída pela comunidade de iguais (corpo místico, comunhão e povo de Deus). Os dados indicam uma consciência eclesial mais individualizada, seja pelas posturas isolada/fragmentadas dos agentes ao elaborar a respostas, seja a visão explicita de uma função espiritual da Igreja distante do mundo. Vale ponderar que, conforme já foi indicado anteriormente, as duas respostas majoritárias na primeira questão se refiram à presença ativa da Igreja no mundo, porém em uma percepção genérica que deve ser completada com as respostas menos consensuais, porém mais concretas. Essas mostram, de fato, uma Igreja mais individualizada e temerosa de uma inserção efetiva na sociedade.

A presença invisível do clericalismo confirma essa mesma postura quando as duas perspectivas desvalorizam a formação do leigo que fica posicionada em $6^{\circ}$ lugar e com índices muito baixos nas respostas de cada agente, sobretudo na perspectiva institucional/carismática. Uma Igreja assentada na segurança institucional do ministério ordenado pode, de fato, indicar o que sobrou do processo de renovação eclesial centrado no valor da igualdade dos batizados, nos laços comunitários, no projeto comum de construção do povo de Deus dentro da história, no horizonte comum do Reino de Deus. Uma Igreja mais autocentrada e distante da sociedade subjaz às respostas diversas e divergentes de ambas as perspectivas ou tendências. 
Do ponto de vista externo, a crise se mostra mais visível. A distância do social possui um índice emblemático na primeira interrogação: 0 fortalecimento da pastoral social aparece em $6^{\circ}$ lugar para as duas perspectivas e revela índices baixos para ambas (exceção dos seminaristas da perspectiva evangelização/libertação). Em terceiro lugar posiciona-se a ideia do exercício da profecia sem confrontações para as duas perspectivas. Os jovens da perspectiva institucional/carismática são unânimes em afirmar uma missão espiritual da Igreja (24,0\%) seguidos dos 14,0\% dos leigos da perspectiva evangelização/libertação.

Não se trata, evidentemente, de uma crise isolada de utopias eclesiais, mas de uma consciência eclesial afinada e, em boa medida, reprodutora das crises das utopias sociais e dos projetos comuns que se mostraram cada vez mais factuais e determinantes no mundo globalizado, mais individualizado, hedonista e imediatista. As expressões eclesiais indolores ganham força com seus agentes patrocinadores; eficácia espiritual/individual colocam em crise modelos de vida eclesial que exijam mobilização de mudança coletiva dentro e fora da Igreja (LIPOVETSKY, 2005).

\section{O que restou do Vaticano II?}

A pergunta indica o rumo das considerações; aponta para o epicentro das mudanças eclesiais/eclesiológicas desde a conclusão do grande evento em 1965; ${ }^{1}$ convida concretamente a olhar como essas duas perspectivas teológico-pastorais ou tendências eclesiais - e os dois grupos de padres estão ou estiveram vinculadas à fonte conciliar.

Logo após a conclusão do Vaticano II, Paulo VI utilizou a metáfora da fonte para falar dos desafios e compromissos imediatos de todo o povo de Deus na audiência de 6 de janeiro de 1966. Dizia que o Concílio é como um rio que corre e dele devemos beber de agora em diante (KLOPPENBURG, 1966,

\footnotetext{
${ }^{1}$ As reflexões sobre o que restou do Vaticano // estão deliberadamente alocadas no contexto em que a pesquisa foi realizada e de onde as tendências eclesiais são inferidas, quando não se pode incluir por razões metodológicas os impactos do pontificado do Papa Francisco na vida da igreja, o que, necessariamente, revelaria novos quadros eclesiais e exigira o uso de novas categorias de análise.
} 
p. 519). A fonte conciliar ofereceu uma água renovadora para toda a Igreja, mas como toda fonte exigiu que a ela se achegasse e que dela se retirasse a água em volume e com a vasilha disponibilizada. O Vaticano II regou e fecundou a Igreja, porém em doses e lugares diferenciados e, em alguns setores da Igreja, sequer chegou a acontecer. E não se trata somente de uma geopolítica eclesial diferenciada, mas de uma percepção sobre os alcances do aggiornamento no conjunto da vida da igreja.

a) Os limites do aggiornamento

As renovações conciliares provocaram, sem dúvidas, viradas copernicanas, porém quase sempre localizadas no âmbito cultural (novas eclesiologias) e social (novas formas de organização eclesial e de ação pastoral) e não no âmbito político-institucional (CASTELLS, 2015, p. 353-354), ou seja, renovaram-se as ideias, os valores e as práticas eclesiais, mas a instituição permaneceu a mesma em suas estruturas e funções. Além das reformas litúrgicas que constituíram a esfera mais visível das mudanças, a teologia da Igreja foi, sem dúvidas, a mais expressiva, seja na reelaboração da compreensão de sua natureza (comunalista) e de sua missão (testemunho e serviço). As igrejas da América Latina foram protagonistas ativas e criativas desse processo renovador.

As reformas eclesiológicas provocaram impactos sociais e políticos muito concretos no conjunto da Igreja, ou seja, nos sujeitos e nos projetos eclesiais, mas estiveram longe de provocar mudanças eclesiásticas condizentes. A teologia pautada na igualdade dos batizados não se traduziu em uma estrutura condizente: permaneceram a mesma estrutura e a mesma organização hierarcológicas herdadas do passado. Se houve mudança institucional, foi apenas periférica ou adaptada às estruturas sedimentadas e teologicamente fundamentadas. A estrutura institucional permaneceu centralizada como dantes, clericalizada e autocentrada e contando com os seus centros gestores de sempre. Os ministérios permaneceram centralizados, hierarquizados e sacerdotalizados. As renovações significativas que aconteceram no conjunto se deram, em alguma medida, na esfera do funcional e não do estrutural. Nesse sentido, a figura de um padre clericalista 
não somente não é nova como encaixa-se legitimamente em um sistema eclesial que se entende como estável, imutável e sagrado.

O resultado final do Concílio carrega essa defasagem entre as esferas do cultural e do institucional, sabendo, com efeito, que toda mudança se conclui quando se traduz institucionalmente. A organização eclesial (e eclesiástica) permaneceu onde sempre esteve em seus centros decisórios e postos de comando em um regime descendente de exercício do poder: com o Papa e a Cúria romana, os bispos com sua cúria, os presbíteros com suas paróquias. Enquanto as mudanças culturais tiveram vigor suficiente para provocar mudanças políticas nos perfis dos sujeitos eclesiais diversos e nos projetos eclesiais, a velha estrutura conheceu formas novas de organização que arrefeciam e, até mesmo, impactavam suas fixações institucionais canonicamente fundamentadas (ELZO, 2016). Na medida em que o carisma renovador caia na rotina (por razões diversas), o aparelho institucional reaparecia como o porto seguro da identidade, da legitimidade e da ação pastoral. O clericalismo retornou com toda força e legitimidade, a estrutura burocrática se apresentou como forma segura de ser Igreja e a consciência eclesial coletiva cedeu lugar a novos modos de participação, nitidamente mais passivos, individualizados ou isolados em determinados grupos.

b) As frentes visíveis e conflitivas

As duas perspectivas ou tendências verificadas constituem frentes mais ou menos agregadas e agregadoras. Configuram identidades eclesiais distintas que, bebendo da mesma fonte, o Vaticano II, foram construindo perfis diferenciados em função das conjunturas e das interpretações mais ou menos hegemônicas. Após o Concilio pode-se pensar, portanto, em duas identidades eclesiais que vão sendo construídas, uma identidade legitimadora, feita da tradição, da doutrina e da instituição eclesial e que avança na busca de hegemonia no campo católico e uma identidade de projeto feita dos ideais renovadores que também busca formas de concretização junto aos atores eclesiais (CASTELLS, 2001, p. 24). A identidade legitimadora goza de vantagens políticas no seio do grupo social por falar em nome da oficialidade e da autopreservação. É sempre autocentrada, auto- 
preservadora e auto-reprodutora. A identidade de projeto é jogada o seu próprio destino. Nos termos de Bourdieu (2003), as reformas precisam sempre de armas discursivas e estratégias políticas para concretizar seus projetos. A luta entre preservação e renovação, inerente a toda instituição, de modo inevitável nas instituições religiosas que se alimentam sempre de fontes originantes com suas forças normativas, constrói conjunturas políticas diferenciadas no decorrer da história, a depender de variáveis diversas.

Os sujeitos e as regras institucionalizadas se sobrepõem aos sujeitos e projetos reformadores precisamente por serem legítimos, na medida em que portadores da oficialidade (da estabilidade e da segurança) e detentores de capitais simbólicos e materiais. Dessa forma, no processo de reforma do Vaticano II a identidade legitimadora gestada pelos agentes oficiais, se sobrepôs às reformas/reformadores, na medida em que a história avançava com suas novas variáveis e o carisma se rotinizava, não obstante os esforços de renovação. É quando o clero ocupou o lugar do leigo, a paróquia assimilou as CEBs, a ritualidade se sobrepôs à práxis social e política, o espiritual assimilou a pastoral, a assistência individual os projetos coletivos. As frentes renovadoras permaneceram contando com a força de seus próprios discursos reformadores, cada vez mais restrito a grupo de sujeitos sempre mais diminutos e portadores de um carisma que se torna cansado de guerra.

c) Um processo histórico-eclesial

Nenhum processo histórico tem percursos previamente previstos. Os ideais de renovação vão modificando os valores e percepções, agregando sujeitos em torno de projetos concretos mais ou menos eficazes politicamente, construindo formas institucionalizadas de sobrevivência, porém em um jogo de forças históricas sempre aberto e sujeito a variadas modificações, desvios e, até mesmo, extinções. Em outros termos, os projetos só podem ser avaliados após suas efetivações concretas. É quando se torna possível verificar retrospectivamente o que contribuiu para as pretendidas realizações e detectar as variáveis favoráveis e contrárias. Com o projeto de aggiornamento conciliar não foi diferente. A história da Igreja na América latina narra nesse meio século da era conciliar as lutas concretas, as 
eficácias e os fracassos nas suas cinco Conferências Gerais do Episcopado, na reflexão teológica, nas formas de organização eclesial e nas práxis pastoral.

Chegamos aqui com as matérias primas e as ferramentas retiradas da fonte conciliar, contando com as variáveis favoráveis de dentro e de fora da Igreja. De dentro a própria ambiguidade da renovação, como já foi dito acima. De fora, as rápidas transformações mundiais do final de século XX e início do XXI foram sendo traduzidas em mudanças eclesiais, de modo espontâneo ou não. Vivenciamos rupturas globais e estruturais que avançam desde o final do século passado no conjunto da sociedade cada vez mais mundializada. A Igreja está inserida com suas contradições internas dentro de rupturas mais amplas e radicais e com elas se relacionam de modo dialético negando, isolando-se ou assimilando. A sociedade globalizada mistura de forma confusa o mais extremo individualismo com novos comunitarismos, destradicionalização e retradicionalização, dessocialização e ressocialização, crença e descrença, tecnociência e magia (TOURAINE, 1999, p. 49-57). A Igreja vivencia essas contradições que demarcam uma sociedade em mudança que saiu de uma identidade comunal edificada sobre consensos sociais, políticos e institucionais para uma sociedade dominada pelo econômico e pelo individualismo consumista, sem gestão local ou mundial. Ainda aguardamos uma Polis do mundo globalizado que reduziu a pedaços as garantias do mundo moderno, como constata o Papa Francisco na Fratelli Tutti (FT 9-55).

d) Os pedaços do aggiornamento

"Os sonhos desfeitos em pedaços" (FT 10), imagem utilizada por Francisco para designar os retrocessos sociais, políticos e culturais em nossos dias de mundo globalizado, pode ser usada para designar os sonhos de João XXIII, da maioria dos padres conciliares e da geração que abraçou a renovação da Igreja como causa e projeto. Hoje parece haver uma perda cada vez mais visível da identificação cultural com o Vaticano II. "A identificação cultural se refere à existência de conjuntos específicos de valores e crenças nos quais grupos humanos específicos se reconhecem”, explica Castells. Ela resulta de geopolíticas mais amplas e de projetos de "organização humana de identidade" (2015, p. 171). O esvaziamento dos projetos de renovação e a 
retomada das zonas de conforto (teológico, social e político) da estrutura institucional católica instaurou concomitantemente conflitos de identidades clericais (e evidentemente laicais) no seio da Igreja. A distância da fonte conciliar e seu gradativo esfriamento e esquecimento (rotinização do carisma) seguiu pari passu a afirmação de um projeto revisor do Concílio conduzido e alimentado pelo centro(s) gestor(s) da Igreja. Não se trata somente de um desgaste histórico natural do projeto renovador, mas de uma identidade que foi sendo construída e ainda se encontra em construção. Portanto, a figura do novo padre não nasce por geração espontânea, mas resulta de um projeto identitário que foi sendo afirmado como necessário para a vida da Igreja. A perda da identificação com o Vaticano II se dava como adesão a outro projeto justificado por outras teologias, sabidamente, por uma eclesiologia marcada ambiguamente por individualismo e tradicionalismo. A classificação utilizada na pesquisa "institucional/carismática" para designar esse perfil de padre expressa com precisão essa ambiguidade eclesial e social. Se em princípio uma práxis tradicional não comportaria individualismo, por colocar de frente a norma objetiva com os valores individuais, o que se constata hoje é, de fato, um encaixe efetivo que combina ambas as posturas. De um lado uma tradição/instituição que oferece capitais simbólicos normativos e mágicos que solucionam as demandas individuais por salvação dentro de um mundo em crise, de outro os próprios indivíduos com cidadania cada vez mais reduzida que encontra amparo materno que os mantenha na menoridade eclesial, dependente do clero. $\mathrm{O}$ tradicionalismo se alimenta dos indivíduos passivos e esses das seguranças de que necessitam. Parece configurar hoje na Igreja católica uma síntese curiosa entre Trento (Igreja autocentrada em suas doutrinas e normas) e individualismo religioso pentecostal (individualidade religiosa autocentrada na santa emoção). Tradição líquida e individualismo sólido? A relação homofílica constitutiva das bolhas sociais virtuais (SANTAELLA, 2019, p. 17-19) parece mostrar sua efetividade na relação entre os indivíduos no interior da instituição eclesial. Uma segurança emocional multilateral cimenta e dinamiza a vida eclesial nesse registro emocional. 
Restam pedaços rarefeitos do aggiornamento conciliar praticado na América Latina. A imagem da renovação eclesial vai retraindo-se, na medida em que uma imagem da conservação se reforça e ganha fôlego nas mídias de um modo geral. A figura cada vez mais central do padre na vida da Igreja emerge com nitidez imagética (com estética distinta), com função de eficácia (simbólica ou administrativa), com força institucional (concentração das decisões pastorais) e com missão espiritual individualizada e distante das realidades sociais. As tipificações feitas pelo Papa Francisco para designar as tendências eclesiais (denominadas como mundanismo espiritual) na Exortação Evangelii gaudium (93-97) retratam com realismo crítico o que pode significar o clericalismo atual.

e) Processo de desmodernização

A Igreja vivencia suas dinâmicas em sintonia direta com os processos sociais; resiste e reproduz esses processos em seus modos de viver e de relacionar internamente. A crise acima indicada não se trata, portanto, de uma crise endógena, mas de uma crise e grande medida reflexa de uma crise social mais ampla que Alain Touraine denominava desmodernização há mais de vinte anos (1999, p. 29-67). A desmodernização tem seu correspondente da descomunização da Igreja. O esvaziamento da consciência de pertença coletiva (ideais, projetos, práticas e regras comuns) atingem a sociedade e a Igreja como centralidade do indivíduo, como destradicionalização dos valores comuns, como pragmatismo consumista e como perda do protagonismo do sujeito.

O que era comum foi sendo suplantado pelo individualizado. O sujeito eclesial, que se definia por sua missão como leigo na Igreja, foi sendo superado pelo indivíduo religioso que se define por si mesmo como paciente religioso ávido de serviços religiosos espirituais. A mesma ruptura detectada por Touraine entre indivíduo e ação (1999, p. 44) na sociedade desmodernizada, o que faz desaparecer a própria noção de sujeito. 0 clericalismo em alta não é mais que um sintoma dessa crise do sujeito eclesial, onde alguns servidores assumem a tarefa de servir religiosamente aos despossuídos de "poder sagrado" e buscam cada vez mais as performances de um servidor religiosamente poderoso. E uma Igreja cada vez mais 
midiatizada confirma de modo excelente a dicotomia entre individualidade eclesial e ação na comunidade eclesial e na vida social e política. Midiatização eclesial é, ao mesmo tempo, expressão e motor de uma Igreja mais clericalizada e descomunizada. Uma Igreja distante do mundo confirma igualmente essa postura na medida em que se autorreferencia como uma comunidade que vive para si mesma e já não se define por sua ação transformadora no mundo.

A instituição eclesial - com sua tradição segura e suas estruturas burocráticas - se mostra não tanto como o padrão comum de vida como no passado, mas como o habitat seguro para o serviço individualizado e para a satisfação dos anseios dos consumidores religiosos, no âmbito de uma marca comum que fornece identidade. A tradição, a doutrina e a práxis eclesiais se tornam cada vez mais meios de acesso a serviços religiosos capazes de emocionar, oferecer prosperidade e libertar das desgraças do mundo presente. É nesse ponto que se amalgamam o institucional com $O$ carismático, os tradicionalismos clássicos com os fundamentalismos modernos. A lgreja é o caminho de acesso ao poder de Deus.

f) Identidades em construção

Os Concílios compõem a construção permanente da identidade católica como momentos de retorno às fontes e de diálogo com o mundo presente. $O$ pontificado atual é a demonstração concreta dessa dinâmica muitas vezes ocultada por um tradicionalismo sempre reincidente (PASSOS, 2020). As identidades ministeriais hora configuradas na Igreja do Brasil revelam um momento do processo de aggiornamento conciliar; momento concreto resultado de projetos eclesiais e de assimilações das tendências históricas. A lição realista da configuração pode apontar para várias questões históricas e eclesiais que exigem ir além da visão espontânea ou fatalista, porém assegura a necessidade de construção permanente do projeto conciliar. No ethos católico um Concílio existe para ser vivenciado; constitui uma fonte de inspiração e orientação para toda igreja. Trata-se de um conjunto de valores que busca os meios de tradução social e política no tempo e no espaço, como última palavra do magistério extraordinário. 0 
Vaticano II está em pleno curso e continua oferecendo referências teológicas para os dias atuais e pedindo traduções concretas nos papéis exercidos pelos cleros e leigos. Esses perfis ainda não foram concluídos e permanecem em construção alimentados pelas referências conciliares.

Por certo ainda não assimilamos a realidade concreta dos processos de recepção, sempre lentos, dialéticos e não lineares. Nesse sentido, o Vaticano II é ao mesmo tempo fonte e meta, projeto a ser afirmado a cada geração. Vale para a Igreja o que Francisco observa sobre as conquistas históricas: "cada geração deve fazer suas as lutas e as conquistas das gerações anteriores e levá-las a metas ainda mais altas. É o caminho" (FT 11).

\section{Referências}

ALMEIDA, J. A. Aggiornamento. In: PASSOS, J. D.; SANCHEZ, W. L. (Coord.) Dicionário do Concílio Vaticano II. São Paulo: Paulus/Paulinas, 20015. p. 8-9.

BOURDIEU, P. A economia das trocas simbólicas. São Paulo: Perspectiva, 2003.

BRIGHENTI, A. Em que o Vaticano II mudou da Igreja. São Paulo: Paulinas, 2016.

CASTELLS, M. O poder da identidade. São Paulo: Paz e Terra, 2001.

CASTELLS, M. O poder da comunicação. São Paulo: Paz e Terra, 2015.

ELZO, J. ¿Quién manda en la iglesia? Notas para una sociología del poder en la iglesia católica del siglo XX. Madrid: PPC, 2016.

FOUREZ, G. A construção das ciências; introdução à filosofia e à ética das ciências. São Paulo: Unesp, 1995.

GADAMER, H.-G. Verdade e método; traços fundamentais de uma hermenêutica filosófica. Petrópolis: vozes, 2002.

FAGGIOLI, M. Vaticano Il; a luta pelo sentido. São Paulo: Paulinas, 2013.

FRANCISCO. Exortação Evangelii Gaudium. São Paulo: Paulinas, 2013.

FRANCISCO. Encíclica Fratelli tutti; sobre a fraternidade e a amizade social. São Paulo: Paulinas, 2020.

KLOPPENBURG, B. Concílio Vaticano II. Vol. V Petrópolis: Vozes, 1966.

LIPOVETSKY, G. A sociedade pós-moralista; o crepúsculo do dever e a ética indolor dos novos tempos democráticos. Barueri: Manole, 2005. 
LIBANIO, J. B. Volta à grande disciplina. São Paulo: Loyola, 1984.

PASSOS, J. D. Concílio Vaticano II; reflexões sobre um carisma em curso. São Paulo: Paulus, 2015.

PASSOS, J. D. A força do passado na fraqueza do presente; o tradicionalismo e suas expressões. São Paulo: Paulinas, 2020.

SANTAELLA, L. A pós-verdade é verdadeira ou falsa? Barueri: Estação das letras e cores, 2019.

TOURAINE, A. Poderemos viver juntos: iguais e diferentes. Petrópolis: Vozes, 1999.

WEBER, M. Economía y sociedad. México: Fondo de Cultura Económica, 1997. 